\title{
A Comparative Analysis of Genetic Diversity in Chrysanthemum (Dendranthema grandiflora Tzvelec) Cultivars based on RAPD and ISSR Markers
}

\author{
P. Lalitha Kameswari* and A. Girwani
}

Floricultural Research Station, Dr.YSR Horticultural University, Hyderabad- 500030, India *Corresponding author

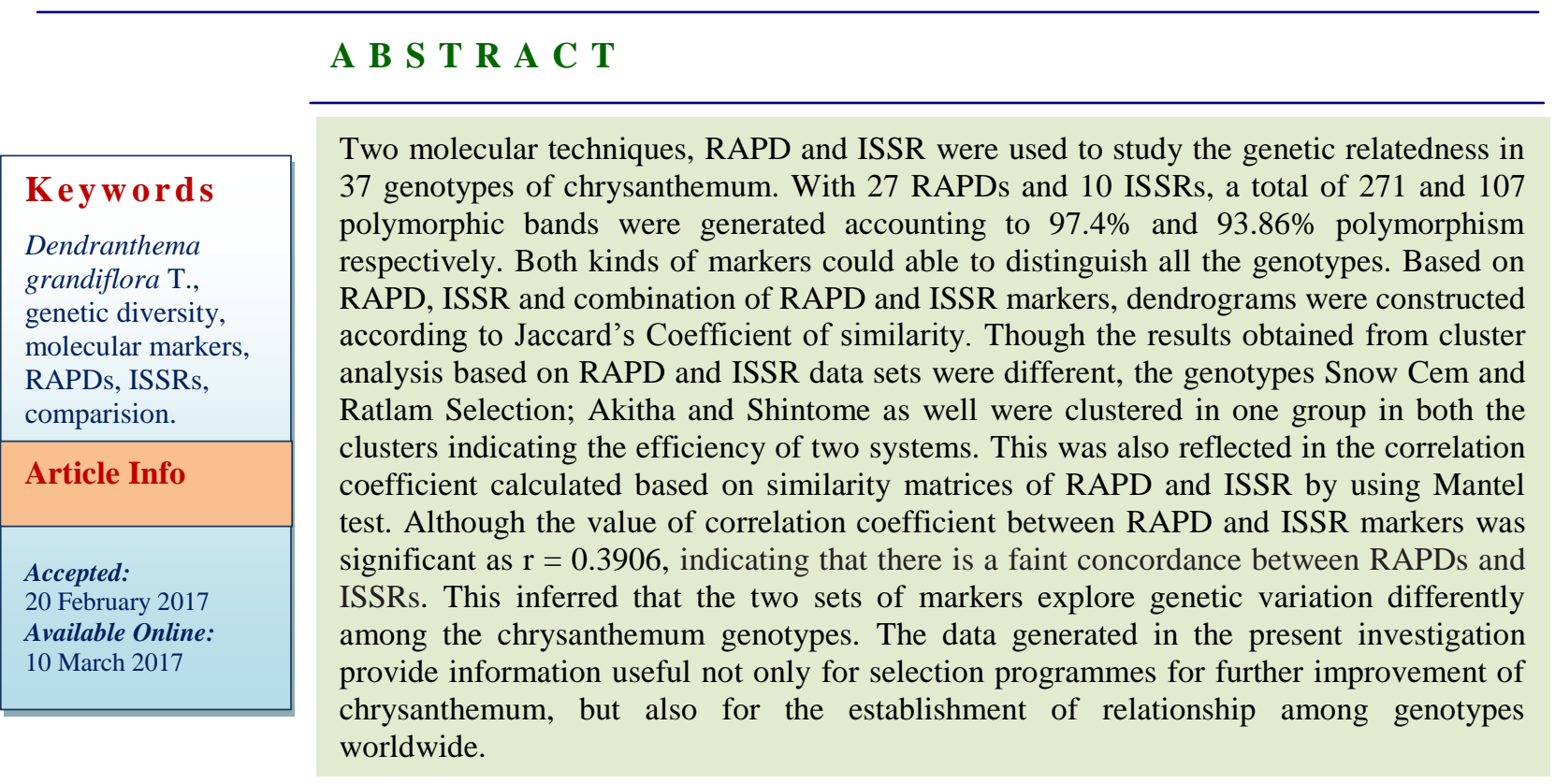

\section{Introduction}

Chrysanthemum (Dendranthema grandiflora Tzvelec), a herbaceous perennial flowering plant has been much loved by the people world-wide as a cut flower. It is one of the oldest cultivated flower crop which plays a significant role in the culture and life of people. Today Chrysanthemums can be found with most of the colours of the spectrum and the pot-mum production has become the most profitable form of commercial Chrysanthemum growing. Economy of space, time, material, etc. has made this style of growing very promising and an excellent range of colour, form, long lasting quality of blooms and ease in handling make them most popular. Because of its multifarious traditional uses, the crop has its own commercial value and a good number of varieties have been released.

The commonly grown Chrysanthemums are hexaploids with average number of 54 chromosomes (Wolff, 1996). The modern, large, double and exquisitely flowered cultivars owe their origin to relatively small, single and non attractive types. This great 
transformation is the result of centuries of natural cross pollination, spontaneous and intentional hybridization coupled with mutation, chromosomal differentiation and polyploidy (Nazeer and Khashoo, 1982). Most extensive work has been done for developing novel Chrysanthemum genotypes through induced mutation using physical and chemical mutagens (Broetjes and Van Harten, 1978).

Since most of the ornamental plant improvement programs concentrate on aesthetic qualities such as flower and plant characteristics, the genetic base of the modern cultivars is becoming more and more narrow. Coupled with global marketing and adoption of these cultivars worldwide, many heir loom varieties of these crops are being replaced by modern narrow genetic base cultivars, resulting in continuous loss of our traditional cultivars. Hence, characterization of germplasm is essential to provide information on the traits of accessions assuring the maximum utilization of the germplasm collection for the benefit of end user. The assessment of diversity based on morphological parameters has been often constrained by lack of precise data on distinguishable morphological characters and their weakness of environmental influence. With the advent of molecular biology techniques, DNA based markers played a significant role in the identification and characterization of germplasm. The first study on the identification of Chrysanthemums with the application of RAPD markers was carried out by Wolff and Peters-Van Rijn (1993).Considering the potentials of the DNA marker based genetic diversity analysis, the present study aimed to evaluate the usefulness of molecular markers viz. RAPD and ISSRs, in assessing and analysing the nature and the extent of genetic diversity among the genotypes of Chrysanthemum.

\section{Materials and Methods}

\section{Plant Material}

The plant material used for the study consisted of 37 genotypes of Chrysanthemum listed in Table 1, collected from germplasm block of Chrysanthemum belonging to Floricultural Research Station, Rajendranagar, Hyderabad.

\section{DNA Isolation}

Total genomic DNA was extracted from fresh, young leaves of Chrysanthemum following the standard CTAB method (Cetyl Trimethyl Ammonium Bromide) with minor modifications (Murray and Thompson, 1980). RNA was removed by digesting with RNaseA $\left(10 \mathrm{mmol} \mathrm{dm}^{-3}\right)$. Purity of DNA was assessed electrophoretically on $0.8 \%$ agarose gel stained with ethidium bromide in comparison with standard DNA ladders and the concentration and quality of DNA was also estimated spectrophotometrically by using Nano Drop spectrophotometer at $260 \mathrm{~nm}$. The template DNA samples were diluted to make the working solutions of $5 \mathrm{ng} / \mu \mathrm{l}$ for PCR analysis.

\section{RAPD PCR - amplification}

Total 124 primers (Operon, USA) were screened out of which 27 decamers belonging to OPE, OPH, OPI, OPF, OPG, OPK, OPJ, OPL and OPM series were selected for PCR amplification of genomic DNA of Chrysanthemum genotypes. List of primers used in the study was furnished in Table 2.

The RAPD reaction mixture consisted of $5 \mathrm{ng}$ of template DNA, 1x PCR buffer (10 mMTris $\mathrm{pH} 9.0,50 \mathrm{mMKCl}, 1.5 \mathrm{mM} \mathrm{MgCl} 2), 100$ $\mathrm{mM}$ of each of the four dNTPs, $0.4 \mathrm{mM}$ of RAPD primer and 0.3 Units of TaqDNA polymerase (Bangalore Genei, India) in a 
reaction volume of $10 \mu \mathrm{l}$. Amplifications were carried out in a Gene Amp 9700 thermal cycler (Perkin Elmer Applied Biosystems) with initial denaturation at $94^{0} \mathrm{C}$ for 3 minutes followed by 45 cycles of 1 min at $92^{0}$ $\mathrm{C}$, annealing temperature of $37^{\circ} \mathrm{C}$ for $30 \mathrm{sec}$ and primer extension at $72^{\circ} \mathrm{C}$ for $2 \mathrm{~min}$ and final extension at $72^{0} \mathrm{C}$ for $7 \mathrm{~min}$. The PCR amplified products were separated electrophoretically on $1.0 \%$ agarose gels. The gel images were recorded using the Alpha Innotech Fluorchem gel documentation system and the sizes of amplification products were determined by comparison to Eco RI and Hind III double digest (Bangalore Genei, India) as molecular weight standard. The reproducibility of the amplification was confirmed by repeating each experiment two times.

\section{ISSR PCR - amplification}

A set of 46 UBC primers (UBC primer set No. 9, University of British Columbia, Canada) were screened out of which 10 primers were used for ISSR amplification (Table-3).The PCR reaction was carried out in a total volume of $10 \mu \mathrm{l}$ containing $1.0 \mu \mathrm{l}$ of 5 ng template DNA, $1.0 \mu \mathrm{l}$ of $1 \mathrm{x}$ PCR buffer (10 mMTris $\mathrm{pH} 9.0,50 \mathrm{mMKCl}, 1.5 \mathrm{mM}$ $\mathrm{MgCl} 2), 0.2 \mu \mathrm{l}$ of $25 \mathrm{mM} \mathrm{MgCl} 2,0.6 \mu \mathrm{l}$ of $200 \mathrm{mM}$ of each of the four dNTPs, $1.0 \mu \mathrm{l}$ of $0.4 \mathrm{mM}$ ISSR primer and $0.2 \mu \mathrm{l}$ of $0.6 \mathrm{UTaq}$ DNA polymerase (Bangalore Genei, India).

PCR amplifications were performed in a Gene Amp 9700 thermal cycler (Perkin Elmer Applied Biosystems) with initial denaturation at $94^{0} \mathrm{C}$ for 4 minutes followed by 35 cycles of $30 \mathrm{sec}$ at $92^{0} \mathrm{C}, 1 \mathrm{~min}$ at annealing temperature of $45^{\circ} \mathrm{C}\left(+/-5^{\circ} \mathrm{C}\right)$ for $1 \mathrm{~min}$ and primer extension at $72^{\circ} \mathrm{C}$ for $1 \mathrm{~min}$ and final extension at $72^{\circ} \mathrm{C}$ for $7 \mathrm{~min}$. The amplified products were resolved on $1.7 \%$ gel and documented in a gel documentation system (Alpha Innotech Flourchem).

\section{Data Analysis}

Ambiguous bands that could not be easily distinguished were not scored (Williams et al., 1990). A clear band was scored as ' 1 ' and ' 0 ' for the absence of band for each primer. Jaccard's similarity coefficient ( $\mathrm{J}$ ) was used to calculate similarity between pairs of genotypes where, $\mathrm{J}=\mathrm{nx}, \mathrm{y} /(\mathrm{nt}-\mathrm{nz}$ ), nx,y is the number of bands common to genotype $\mathrm{A}$ and genotype $\mathrm{B}$; the total number of bands present in all samples and $\mathrm{nz}$ the number of bands not present in $\mathrm{A}$ and $\mathrm{B}$ but found in other samples. Cluster analysis was performed on molecular similarity matrices using the Unweighted Pair Group Method using Arithmetic means (UPGMA) algorithm, from which dendrograms depicting similarity among genotypes were drawn and plotted using NTSYS-pc. 2.1 Software (Rohlf, 2000).

\section{Results and Discussion}

\section{RAPD Analysis}

A total of 278 amplified fragments were scored with 27 selected RAPD primers, out of which 271 were found to be polymorphic $(97.4 \%)$ (Table-2). The number of DNA fragments amplified per primer ranged from 7 (OPE-15, OPG- 9, OPG-16, OPH-13, OPH$20)$ to 17 (OPK-19) with a mean value of 10.3 bands per primer. The amplification products obtained with primer OPE-18 are illustrated in Fig 1.The amplicon sizes ranged from 350 bp to $3500 \mathrm{bp}$. All the primers except OPE14, OPE-15, OPE-18, OPF-3, OPF-5 and OPI-18 gave highest polymorphism $(100 \%)$.The high polymorphism observed in the present study confirms much diversity existing within this germplasm. The total number of amplified fragments generated per primer had no correlation with proportion of polymorphic bands. Similar pattern was observed by Williams et al., (1993). Genetic similarity based on Jaccard's coefficient 
revealed considerable level of diversity among the genotypes under the study. The similarity index varied from 0.174 to 0.600 with an average of 0.387 among the group of genotypes.

The genotypes Ratlam Selection and Snow Cem were found to be most genetically similar $(60.0 \%)$ followed by Akitha and Shintome with $55.3 \%$ and Terry and Salora with $55.1 \%$. On contrary, Aparajitha and Lilith were found to be the least genetically similar (17.4\%).All the remaining ones exhibited diverse intermediate levels of similarity. The derived UPGMA dendrogram resulted in eleven clusters at a genetic similarity coefficient of 0.23 with Chandrika and Aparajitha at the extreme ends of the dendrogram (Fig 2).The reason for the separation of these genotypes as individual clusters may be due to their different genetic backgrounds. All the 37 genotypes were grouped into four major clusters of which three genotypes were grouped in cluster I, five genotypes in cluster II, nineteen genotypes in cluster III, three genotypes in cluster IV and seven minor clusters with one genotype each in cluster V (Arka Ravi), VI (Meera), VII (Asha), VIII (Silper), IX (Autumn Joy), X (Lilith) and cluster XI (Chandrika).

\section{ISSR Analysis}

Among forty six ISSR primers used in the preliminary analysis, only ten primers generated the scorable PCR products. A total of 114 bands were produced, of which 107 bands were polymorphic, accounting for 93.86\% polymorphism (Table-3).

Table.1 List of genotypes used for molecular studies in Chrysanthemum

\begin{tabular}{|l|l|l|l|}
\hline S.No. & Name of the genotype & S.No. & Name of the genotype \\
\hline 1 & Aparajitha & 20 & Autumn Joy \\
\hline 2 & Punjab Gold & 21 & Anjali \\
\hline 3 & CO-3 & 22 & Akitha \\
\hline 4 & Raichur & 23 & PAU-B-107 \\
\hline 5 & Silper & 24 & Farr \\
\hline 6 & Yellow Gold & 25 & Jaya \\
\hline 7 & Punjab Anuradha & 26 & Harvest House \\
\hline 8 & Rekha & 27 & Lilith \\
\hline 9 & Chandrika & 28 & Asha \\
\hline 10 & Snow Cem & 29 & Pusa Centenary \\
\hline 11 & Meera & 30 & Salora \\
\hline 12 & Shaffoli & 31 & IIHR-13 \\
\hline 13 & Terry & 32 & Basanthi \\
\hline 14 & Shintome & 33 & Red Stone \\
\hline 15 & Arka Ravi & 34 & Geetanjali \\
\hline 16 & Ratlam Selection & 35 & Red Gold \\
\hline 17 & Neelima & 36 & Kalyani Mauve \\
\hline 18 & Flirtation & 37 & Local Button \\
\hline 19 & Mother Teresa & & \\
\hline
\end{tabular}


Table.2 Details of RAPD primers used in Chrysanthemum

\begin{tabular}{|c|c|c|c|c|c|c|}
\hline $\begin{array}{c}\text { S. } \\
\text { No. }\end{array}$ & $\begin{array}{l}\text { RAPD } \\
\text { primer }\end{array}$ & $\begin{array}{c}\text { Nucleotide } \\
\text { sequence }\left(5^{\prime}-33^{\prime}\right)\end{array}$ & $\begin{array}{l}\text { Number } \\
\text { of bands }\end{array}$ & $\begin{array}{c}\text { Total no. of } \\
\text { polymorphic } \\
\text { bands } \\
\end{array}$ & $\begin{array}{c}\text { Percentage } \\
\text { polymorphism } \\
(\mathbf{1 0 0 \% )}\end{array}$ & $\begin{array}{c}\text { Size of } \\
\text { amplified } \\
\text { product(bp) }\end{array}$ \\
\hline 1 & OPE-14 & TGCGGCTGAG & 10 & 9 & 90.00 & $450-3300$ \\
\hline 2 & OPE-15 & ACGCACAACC & 7 & 6 & 85.71 & $830-2000$ \\
\hline 3 & OPE-16 & GGTGACTGTG & 11 & 11 & 100.0 & $420-2600$ \\
\hline 4 & OPE-18 & GGACTGCAGA & 11 & 10 & 90.90 & $600-3300$ \\
\hline 5 & OPE-19 & ACGGCGTATG & 12 & 12 & 100.0 & $440-3000$ \\
\hline 6 & OPF-3 & CCTGATCACC & 9 & 8 & 88.89 & $500-2200$ \\
\hline 7 & OPF-5 & CCGAATTCCC & 8 & 7 & 87.50 & $750-3000$ \\
\hline 8 & OPF-19 & CCTCTAGACC & 10 & 10 & 100.0 & $450-2500$ \\
\hline 9 & OPG-9 & CTGACGTCAC & 7 & 7 & 100.0 & $750-2000$ \\
\hline 10 & OPG-16 & AGCGTCCTCC & 7 & 7 & 100.0 & $800-1600$ \\
\hline 11 & OPG-19 & GTCAGGGCAA & 11 & 11 & 100.0 & $350-2027$ \\
\hline 12 & OPH-13 & GACGCCACAC & 7 & 7 & 100.0 & $600-3000$ \\
\hline 13 & OPH-16 & TCTCAGCTGG & 11 & 11 & 100.0 & $350-1900$ \\
\hline 14 & OPH-17 & AAGCAGCAAG & 11 & 11 & 100.0 & $400-2000$ \\
\hline 15 & OPH-20 & CACCGTTCTG & 7 & 7 & 100.0 & $420-2000$ \\
\hline 16 & OPI-6 & AAGGCGGCAG & 14 & 14 & 100.0 & $560-2000$ \\
\hline 17 & OPI-18 & TGCCCAGCCT & 12 & 10 & 83.33 & $600-3500$ \\
\hline 18 & OPI-19 & AATGCGGGAG & 12 & 12 & 100.0 & $450-2200$ \\
\hline 19 & OPI-20 & AAAGTGCGGG & 11 & 11 & 100.0 & $450-2500$ \\
\hline 20 & OPJ-14 & CACCCGGATC & 13 & 13 & 100.0 & $350-2000$ \\
\hline 21 & OPJ-15 & TGTAGCAGGG & 13 & 13 & 100.0 & $564-3000$ \\
\hline 22 & OPM-10 & TCTGGCGCAC & 9 & 9 & 100.0 & $500-1900$ \\
\hline 23 & OPK-8 & GAACACTGGG & 11 & 11 & 100.0 & $750-2200$ \\
\hline 24 & OPK-18 & CCTAGTCGAG & 9 & 9 & 100.0 & $550-3300$ \\
\hline 25 & OPK-19 & CACAGGCGGA & 17 & 17 & 100.0 & $450-2500$ \\
\hline 26 & OPL-1 & GGCATGACCT & 8 & 8 & 100.0 & $450-2200$ \\
\hline 27 & OPL-18 & ACCACCCACC & 10 & 10 & 100.0 & $600-2000$ \\
\hline
\end{tabular}

Source: Operon Technologies, INC. 1000 Atlantic Avenue Suite 108, Alameda, CA 
Table.3 Details of ISSR primers and amplified bands of all the DNA samples as obtained from thirty seven genotypes of Chrysanthemum

\begin{tabular}{|c|c|c|c|c|c|c|}
\hline $\begin{array}{c}\text { S. } \\
\text { No }\end{array}$ & Primer & $\begin{array}{c}\text { Annealing } \\
\text { temperature } \\
\left({ }^{0} \mathbf{C}\right)\end{array}$ & $\begin{array}{c}\text { DNA } \\
\text { repeats }\end{array}$ & $\begin{array}{c}\text { No. of } \\
\text { total } \\
\text { bands }\end{array}$ & $\begin{array}{c}\text { Polymorphic } \\
\text { bands(\%) }\end{array}$ & $\begin{array}{c}\text { Size range of } \\
\text { amplified } \\
\text { product(bp) }\end{array}$ \\
\hline 1 & 808 & $52^{0} \mathrm{C}$ & $(\mathrm{AG})_{8} \mathrm{C}$ & 15 & $15(100 \%)$ & $250-1550$ \\
2 & 810 & $50^{\circ} \mathrm{C}$ & $(\mathrm{GA})_{8} \mathrm{~T}$ & 8 & $8(100 \%)$ & $220-1800$ \\
3 & 812 & $50^{\circ} \mathrm{C}$ & $(\mathrm{GA})_{8} \mathrm{~A}$ & 9 & $9(100 \%)$ & $400-1400$ \\
4 & 825 & $50^{\circ} \mathrm{C}$ & $(\mathrm{AC})_{8} \mathrm{~T}$ & 7 & $5(71.43 \%)$ & $400-1400$ \\
5 & 836 & $53^{\circ} \mathrm{C}$ & $(\mathrm{AG})_{8} \mathrm{YA}$ & 11 & $10(90.91 \%)$ & $250-2000$ \\
6 & 840 & $53^{\circ} \mathrm{C}$ & $(\mathrm{GA})_{8} \mathrm{YT}$ & 12 & $12(100 \%)$ & $300-2000$ \\
7 & 842 & $55^{\circ} \mathrm{C}$ & $(\mathrm{GA})_{8} \mathrm{YG}$ & 12 & $12(100 \%)$ & $420-1900$ \\
8 & 846 & $53^{\circ} \mathrm{C}$ & $(\mathrm{CA})_{8} \mathrm{RT}$ & 12 & $11(91.67 \%)$ & $400-2000$ \\
9 & 855 & $53^{\circ} \mathrm{C}$ & $(\mathrm{AC})_{8} \mathrm{YT}$ & 13 & $11(84.62 \%)$ & $250-1600$ \\
10 & 857 & $55^{\circ} \mathrm{C}$ & $(\mathrm{AC})_{8} \mathrm{YG}$ & 15 & $14(93.33 \%)$ & $220-1550$ \\
\hline & & & 114 & 107 & \\
\hline
\end{tabular}

Fig.1 RAPD profile of 37 genotypes of Chrysanthemum with primer OPE-18

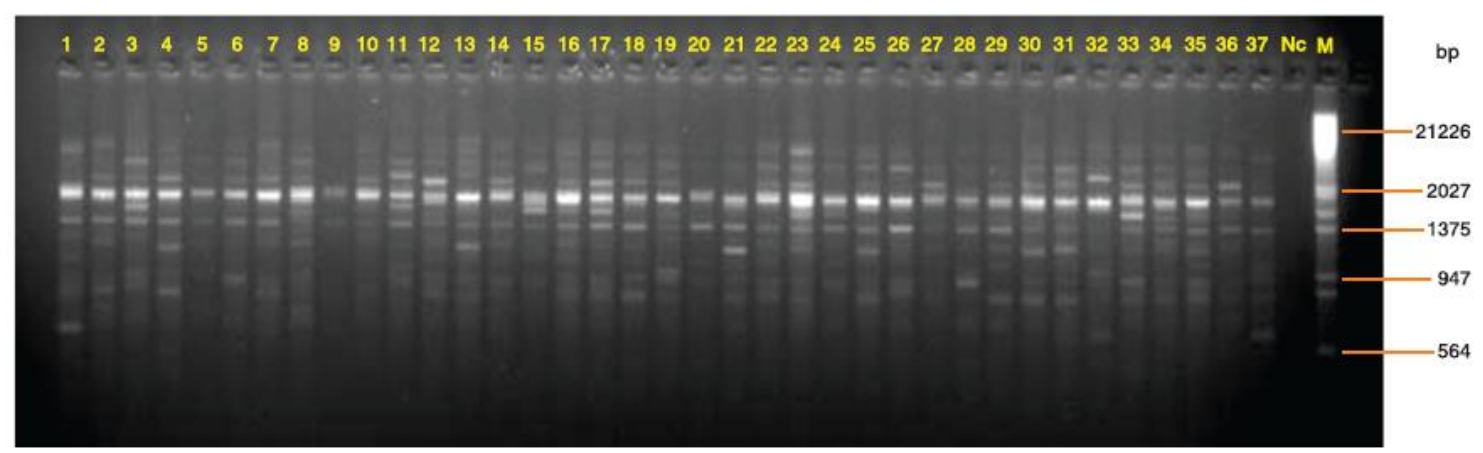

Amplicon size ranged from 600bp to 3300bp. M- marker, EcoR1- Hind III double digest of ג DNA; NC- negative control (no DNA), 1-37 represent the genotypes. Refer table 1 for identity code of these cultivars 
Fig.2 Dendrogram generated using UPGMA analysis showing the genetic relationship among Chrysanthemum genotypes using RAPD data

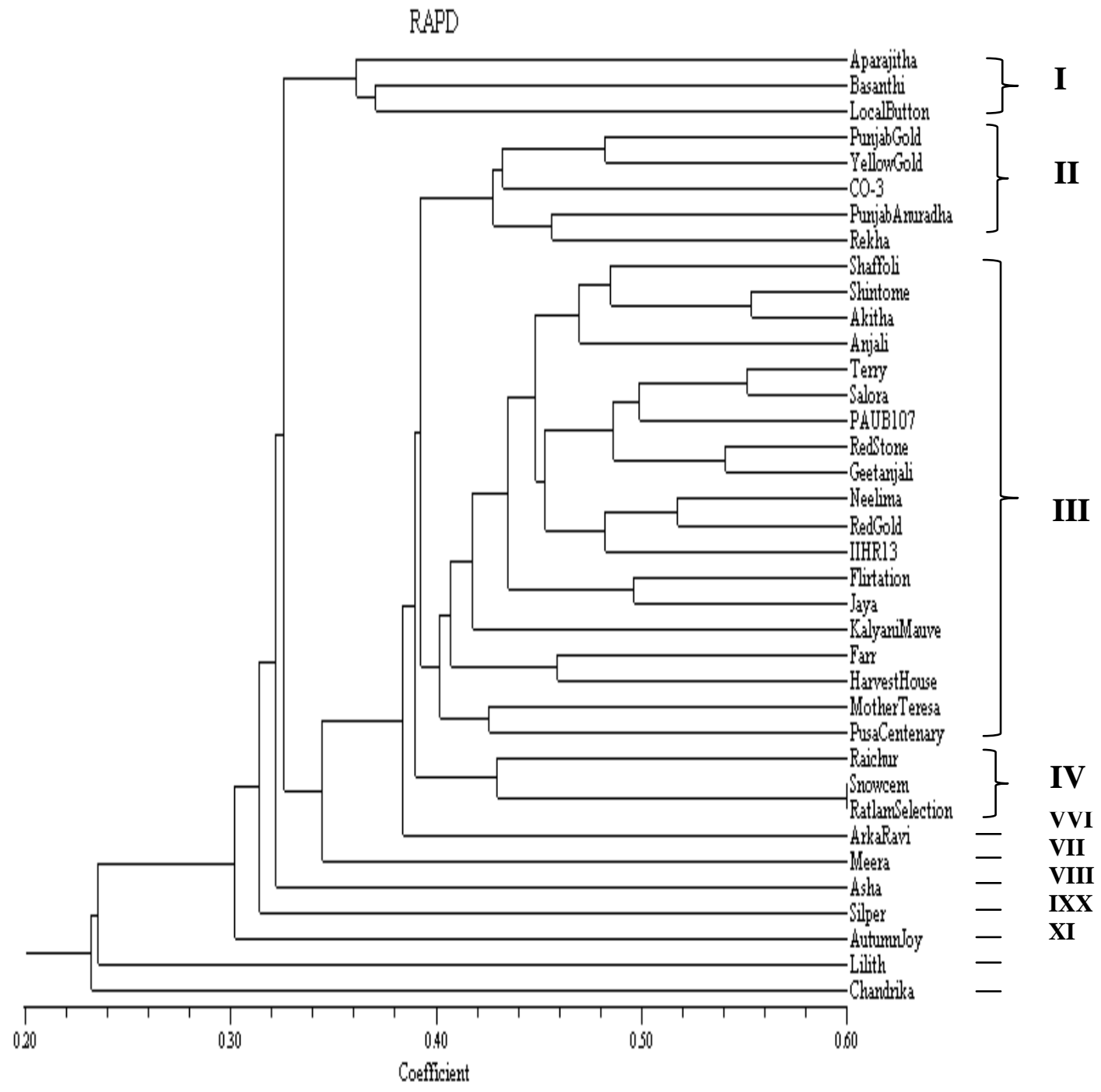


Fig.3 Dendrogram generated using UPGMA analysis showing the genetic relationship among Chrysanthemum genotypes using ISSR data

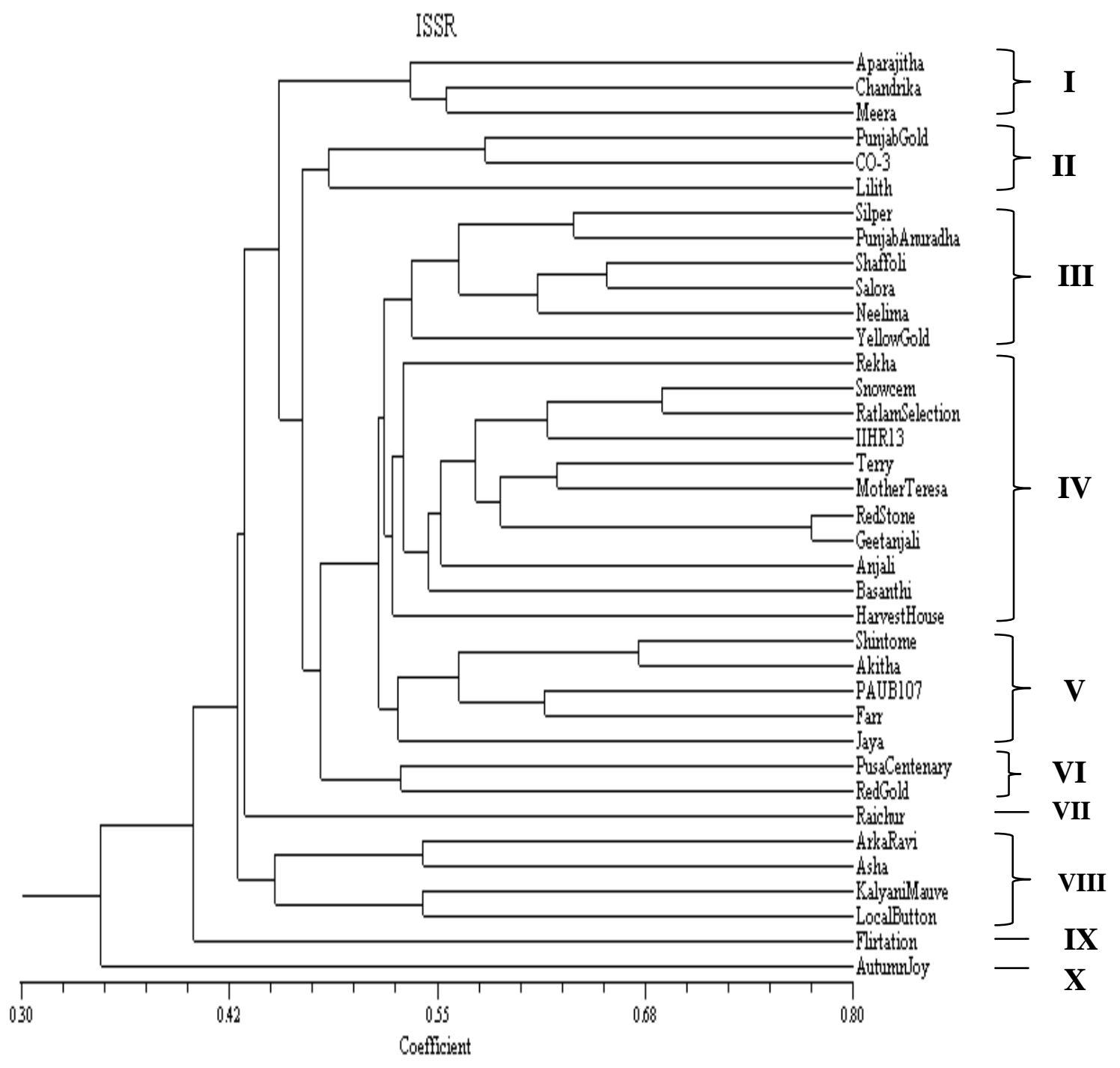


Fig.4 Dendrogram generated using UPGMA analysis showing the genetic relationship among Chrysanthemum genotypes using RAPD + ISSR data

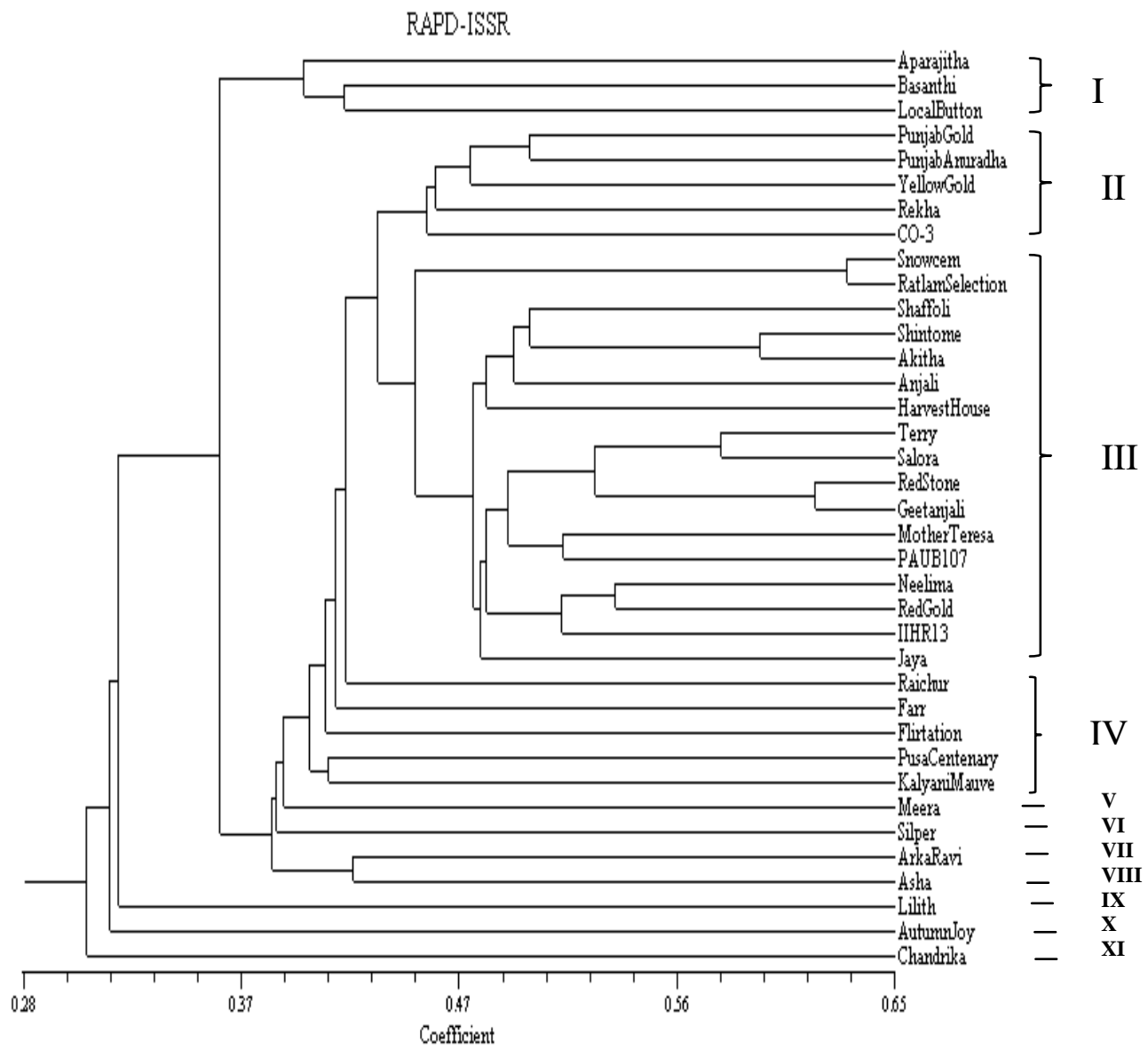

The number of bands varied from 7(ISSR$825)$ to 15 (ISSR-808 and ISSR-857) depending on the primer with a mean value of 11.4 bands per primer. The amplicon sizes obtained with the ISSR primers ranged from $220 \mathrm{bp}$ to 2000bp. The percentage of polymorphism exhibited by ISSR primers ranged from $71.43 \%$ (ISSR-825) to $100 \%$ (ISSR-808, 810, 812, 840 and 842).The genetic similarity matrix ranged from 0.275 to 0.775 with an average of 0.525 . The lowest similarity index (0.275) was scored between Autumn Joy and Flirtation that seem to be most divergent cultivars. The genotypes Geetanjali and Red Stone exhibiting the highest similarity index value of 0.775 , are the most similar cultivars. The derived UPGMA dendrogram (Fig 3) exhibits ten clusters and the pattern revealed that, cluster IV was the largest one consisting of 11 genotypes followed by cluster III with six genotypes. Cluster V included five genotypes, cluster VIII with four genotypes, cluster I and II with three genotypes each, cluster VI with two genotypes and cluster VII, IX and X with one genotype each.

\section{RAPD and ISSR Polymorphism}

The RAPD data was combined with ISSRs in order to precise the relationships between the cultivars studied and a total of 378 polymorphic bands were generated. The similarity coefficients ranged from 0.243 to 0.629 with a mean similarity index of 0.436 . The genotypes Snow Cem and Ratlam 
Selection were almost similar with highest similarity index of 0.629 registered between them. The genotypes Autumn Joy and Basanthi showed lowest similarity index of 0.243. The dendrogram generated (Fig 4) illustrates the divergence among the genotypes. The grouping from combined analysis was similar in composition to that of RAPD. The results obtained from cluster analysis based on RAPD and ISSR data sets were different which was also reflected in the correlation coefficient value of $r=0.3906$ by using Mantel test. This inferred that the two sets of markers explore genetic variation differently. According to the results, both the marker techniques could satisfactorily detect the genetic variation and thereby demonstrates the usefulness of these markers for further use in germplasm characterization of cultivars, including legal issues like assessing infringements on plant breeders rights.

\section{References}

Broetjes, C. and Van Harten, A.M. 1978. Application of mutation breeding methods in the improvement of vegetatively propagated crops. An Interpretative literature review, Elsevier, Amsterdam.
Murray, M. and Thompson, W. 1980. The isolation of high weight plant DNA, Nucleic Acids Res., 8: 4321-4325.

Nazeer, M.A. and Khashoo, R.N. 1982.Cytogenetical evaluation of garden Chrysanthemum, Curr. Sci., 51: 583-585.

Rohlf, F.J. 2000. NTSYS-pc: Numerical Taxonomy and Multivariate Analysis System. Version 2.1 Exceter Software, New York, USA.

Williams, G.K., Kubelik, A.R., Livak, K.L., Rafalski, J.A. and Tingey, S.V. 1990. DNA polymorphisms amplified by arbitrary primers are useful as genetic markers. Nucleic Acids Res., 18: 65316535.

Williams, G.K., Hanafey, M.K., Rafalski, J.A. and Tingey, S.V. 1993. Genetic analysis using randomly amplified polymorphic DNA markers. Methods in Enzymol., 218: 704-741.

Wolff, K. 1996. RAPD analysis of reporting and chimerism in Chrysanthemum, Euphytica, 89: 159-164.

Wolff, K. and Peters-Van Rijn, J. 1993. Rapid detection of genetic variability in Chrysanthemum (D. grandiflora T.) using random primers, Heredity, 71: 335-341.

\section{How to cite this article:}

Lalitha Kameswari, P., and Girwani, A. 2017. A Comparative Analysis of Genetic Diversity in Chrysanthemum (Dendranthema grandiflora Tzvelec) Cultivars based on RAPD and ISSR Markers. Int.J.Curr.Microbiol.App.Sci. 6(3): 2134-2143.

doi: https://doi.org/10.20546/ijcmas.2017.603.244 